Article

\title{
Ionic liquids as eco-friendly catalysts for converting glycerol and urea into high value-added glycerol carbonate
}

\author{
Juanjuan Chen a,b, Chang Wang b, Bin Dong b, Wenguang Leng b, Jun Huang a,*, Rile Ge b, \\ Yanan Gao b,\# \\ a College of Chemistry and Chemical Engineering, Nanjing Tech University, Nanjing 210009, Jiangsu, China \\ ${ }^{\mathrm{b}}$ Dalian Institute of Chemical Physics, Chinese Academy of Sciences, Dalian 116023, Liaoning, China
}

\section{A R T I C L E I N F O}

\section{Article history:}

Received 16 October 2014

Accepted 19 November 2014

Published 20 March 2015

\section{Keywords:}

Glycerol carbonate

Glycerol

Urea

Ionic liquid

\begin{abstract}
A B S T R A C T
Acidic, basic and neutral ionic liquids (ILs) have been used as catalysts in the carbonylation of glycerol with urea. The results show that neutral ILs have high catalytic activity in the reaction. The excellent performance of the catalysts can be attributed to the synergistic effect of the cation and anion. We speculated that the cation with positive charge activates urea, and the anion with negative charge activates glycerol. In addition, the well balanced acid-basic properties of the catalysts are necessary for good catalytic performance. The ILs can be reused at least five times without loss of activity. Using ILs, instead of the traditional metal catalysts, reduces the use of non-renewable resources. It is eco-friendly that two inexpensive and bio-based raw materials were used and the catalytic reaction was carried out without solvent.
\end{abstract}

(C) 2015, Dalian Institute of Chemical Physics, Chinese Academy of Sciences. Published by Elsevier B.V. All rights reserved.

\section{Introduction}

Energy is the basis of human social and economic development, and all countries actively develop renewable energy sources to solve the issue of the increasingly tense shortage of energy supply. As an alternative, non-toxic, and biodegradable renewable fuel, biodiesel is receiving increasing attention. A large amount of glycerol is produced as a by-product in the large scale production of biodiesel [1,2]. The surplus glycerol accumulating as a waste has motivated industrial and academic research towards the identification of new opportunities for converting it into high value-added chemicals based on its structure, renewability, and bioavailability [3].

One important glycerol derivative is glycerol carbonate
(GC), which has gained much interest over the last 20 years. Glycerol carbonate shows a wide range of reactivity due to the presence of a hydroxyl group and a 2-oxo-1,3-dioxolane group, which has both electrophilic and nucleophilic sites. Glycerol carbonate can be used as a bio-based building block for the synthesis of more complex chemicals, such as surfactants, polymers and other chemical intermediates [4]. On the other hand, glycerol carbonate shows low toxicity, low evaporation rate, moisturizing ability, and good biodegradability, making it a very attractive chemical for a variety of applications, e.g., as a wetting agent for cosmetics, a carrier in medical preparations, a component in membranes for gas separation, and as the electrolyte for lithium and lithium-ion batteries [4].

Glycerol carbonate has been synthesized by a number of

\footnotetext{
* Corresponding author. Tel: +86-25-83172276; E-mail: junhuang@njtech.edu.cn

\# Corresponding author. Tel/Fax: +86-411-84379992; E-mail: ygao@dicp.ac.cn

This work was supported by the National Natural Science Foundation of China $(21273235,21303076)$ and the 100-Talents Program of Chinese Academy of Sciences.
} 
methods, which were reviewed by Sonnati et al. [4]. Among these methods, the direct synthesis of glycerol carbonate by the carbonation of glycerol with $\mathrm{CO}$ or $\mathrm{CO}_{2}$ has been studied in the last few years $[5,6]$. The carbonation of glycerol with $\mathrm{CO}$ gave excellent conversion (92\%) and selectivity (>99\%) [5], and the yield of glycerol carbonate was $86 \%$ for the reaction of glycerol with $\mathrm{CO}_{2}$ [6]. But these routes are limited because $\mathrm{CO}$ is toxic and difficult to handle safely in the laboratory and industry, and the direct carbonation of glycerol with $\mathrm{CO}_{2}$ requires high pressure and the use of an organic solvent, which have negative ecological impacts. The commonly used routes to synthesize glycerol carbonate are the reactions of glycerol with phosgene [7] and its transesterification with other carbonates [8-10]. The best results (GC yield 99\%) were obtained by the transcarbonation glycerol with dimethyl carbonate or diethyl carbonate, but it was difficult to separate the product from the reaction. One alternative route is the reaction of glycerol with urea, which has been recently described in the scientific [10-16] and patent literature $[17,18]$. From an ecological point of view, the advantage of this method is that glycerol and urea are both bio-based reactants. Also, this method provides the chemical fixation of $\mathrm{CO}_{2}$. Several catalysts have been used in the carbonylation of glycerol with urea, which were mainly based on Zn-based catalysts and other metal catalysts [11-16]. For example, a high yield of glycerol carbonate (91\%) was obtained using $\mathrm{La}_{2} \mathrm{O}_{3}$ as catalyst and the conversion of glycerol reached 98\% using metal monoglycerolates as catalyst [11]. However, these methods suffer from the serious environmental problems of the use of heavy metals and the non-renewability and exhaustion of mineral resources. Therefore, an eco-friendly catalyst is needed.

As opposed to conventional organic and inorganic solvents, ionic liquids (ILs) have attracted much interest as an environmentally benign medium for catalytic processes or chemical extraction due to their negligible vapour pressure, excellent thermal stability, and high conductivity [19-23]. ILs have been used to support reagents and catalysts. Zwitterionic imidazolium compounds have been shown to act as effective solvent- catalyst for Fischer esterification [24], esterification of aliphatic acids with alkenes [25], and oligomerisation of alkenes [26]. Carboxylic acids have been tethered to ILs by Nockemann et al. [27] for the solubilization of hydroxides and metal oxides. Basic groups have also been attached to ILs by Bates et al. [28] for gas separation. In addition, an amine-attached IL was designed to capture $\mathrm{CO}_{2}$ by ammonium carbonate formation [28]. Recently, the "non-solvent" application of ILs is gaining momentum. For instance, Sarkar et al. [29] reported that 1-alkyl-3-methylimidazolium (bmim) cation based ILs can effectively catalyze $\mathrm{N}$-tertbutyloxycarbonylation of amines with excellent chemoselectivity. They also described hydrogen bond induced reactivity and selectivity control in the reaction of thiols with $\alpha, \beta$-unsaturated carbonyl compounds using bmim-based ILs as solvent and catalyst [30].

The synthesis of cyclic carbonates from epoxides and $\mathrm{CO}_{2}$ catalyzed by ILs has been reported by Park and co-workers [31-36], and the ILs showed good catalytic performance. However, ILs as catalysts in the carbonylation of glycerol with urea has not been reported. In this work, we investigated a series of acidic, basic and neutral ILs (Fig. 1) as catalyst in the carbonylation of glycerol with urea. The reaction was carried out in an environment without solvent. The influence of various reaction parameters such as reaction time, reaction temperature, and molar ratio of reactant to catalyst was studied. The reaction mechanism is discussed. This is the first report of a non-metal catalyst for the carbonylation of glycerol with urea.

\section{Experimental}

\subsection{General}

The chemicals were obtained from commercial suppliers and used without further purification. All the ionic liquids were prepared according to the literature [37-45] and characterized by NMR spectroscopy. ${ }^{1} \mathrm{H}$ and ${ }^{13} \mathrm{C}$ NMR spectra were recorded on a Bruker Advance III $400 \mathrm{MHz}$ NMR spectrometer with TMS as the internal standard at room temperature. A qualitative

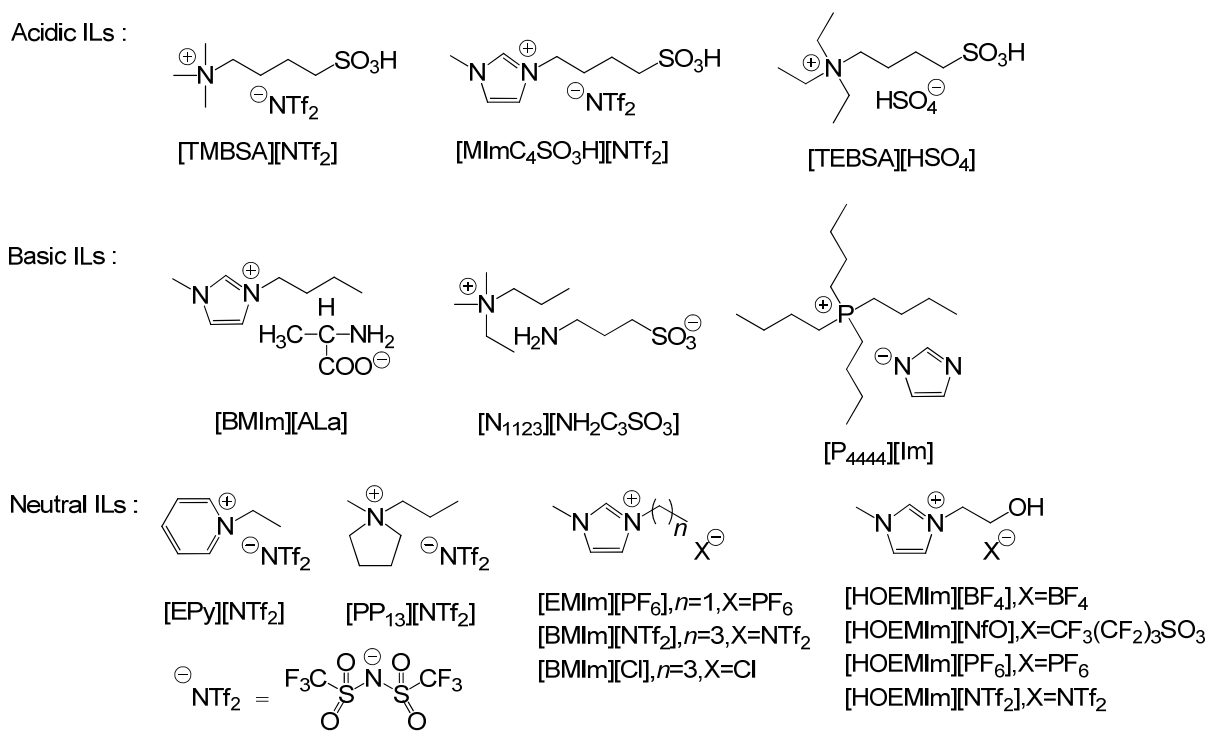

Fig. 1. Structures of the ILs. 
analysis of the product was conducted by ${ }^{1} \mathrm{H}$ and ${ }^{13} \mathrm{C}$ NMR and a quantitative analysis was conducted by ${ }^{1} \mathrm{H}$ NMR.

\subsection{Synthesis and characterization of ILs}

The structures of the ionic liquids used in this work are shown in Fig. 1. The spectroscopic data of all the ILs were in accord with the literature.

$\mathrm{N}, \mathrm{N}, \mathrm{N}$-Trimethyl- $\mathrm{N}$-butanesulfonic acid ammonium bis[(trifluoromethyl)sulfonyl] imide ([TMBSA][NTf 2$]$ ) [37]. ${ }^{1} \mathrm{H}$ NMR (400 MHz, $\left.\mathrm{D}_{2} \mathrm{O}, \delta \mathrm{ppm}\right): 1.566-1.641(\mathrm{~m}, 2 \mathrm{H}), 1.703-1.783(\mathrm{~m}$, 2H), 2.739-2.777 (t, 2H), $2.907(\mathrm{~s}, 9 \mathrm{H}), 3.422-3.164(\mathrm{t}, 1 \mathrm{H}) ;{ }^{13} \mathrm{C}$ NMR (100 MHz, $\left.\mathrm{D}_{2} \mathrm{O}, \delta \mathrm{ppm}\right): 20.993,21.200,50.003,52.818$, $65.899,114.516,117.692,120.874,124.050$.

1-(4-Sulfonic acid) butyl-3-methylimidazolium bis[(trifluoromethyl)sulfonyl] imide ([MImC $\left.\left.{ }_{4} \mathrm{SO}_{3} \mathrm{H}\right]\left[\mathrm{NTf}_{2}\right]\right)$ [37]. ${ }^{1} \mathrm{H}$ NMR (400 MHz, $d_{6}$-DMSO, $\delta$ ppm): 1.545-1.621(m, 2H), 1.843-1.917 $(\mathrm{m}, 2 \mathrm{H}), 2.665-2.703(\mathrm{t}, 2 \mathrm{H}), 3.809(\mathrm{~s}, 3 \mathrm{H}), 4.136-4.172(\mathrm{t}, 2 \mathrm{H})$ $7.604(\mathrm{~s}, 1 \mathrm{H}), 7.670(\mathrm{~s}, 1 \mathrm{H}), 9.076(\mathrm{~s}, 1 \mathrm{H}) ;{ }^{13} \mathrm{C} \mathrm{NMR}(100 \mathrm{MHz}$ $d_{6}$-DMSO, $\left.\delta \mathrm{ppm}\right): 21.761,28.840,36.151,48.963,50.885$, $115.224,118.420,121.618,122.742,124.068,124.815$ 137.138.

$\mathrm{N}$-(4-Sulfonic acid) butyl triethyl ammonium hydrogen sulfate ([TEBSA][HSO 4$]$ ) [37]. ${ }^{1} \mathrm{H}$ NMR (400 MHz, $\left.{ }_{2} \mathrm{O}, \delta \mathrm{ppm}\right)$ : $1.050-1.085(\mathrm{t}, 9 \mathrm{H}), 1.581-1.647(\mathrm{~m}, 4 \mathrm{H}), 2.746-2.781(\mathrm{t}, 2 \mathrm{H})$ 2.977-3.016 (t, 2H), 3.054-3.108 (q, 6H); ${ }^{13} \mathrm{C}$ NMR (100 MHz, $\left.\mathrm{D}_{2} \mathrm{O}, \delta \mathrm{ppm}\right): 6.349,6.403,19.578,20.887,49.755,52.289$, 55.617.

1-Butyl-3-methylimidazolium alanine ([BMIm][ALa]) [38]. ${ }^{1} \mathrm{H}$ NMR (400 MHz, $d_{6}$-DMSO, $\delta \mathrm{ppm}$ ): 0.825-0.862 (t, 3H), 1.027-1.044 (d, 3H), 1.169-1.262 (m, 2H), 1.702-1.775 (m, $2 \mathrm{H}), 2.919-2.949(\mathrm{q}, 1 \mathrm{H}), 3.890(\mathrm{~s}, 3 \mathrm{H}), 4.186-4.222(\mathrm{t}, 2 \mathrm{H})$ 7.836 (s, 1H), 7.898 (s, 1H), 10.015 (s, 1H); ${ }^{13} \mathrm{C}$ NMR $(100 \mathrm{MHz}$ $d_{6}$-DMSO, $\delta$ ppm): 13.187, 18.749, 31.487, 35.469, 48.300, $51.813,122.257,123.574,137.763,178.569$.

Dimethylethylpropylamine aminopropanesulfonic salt $\left(\left[\mathrm{N}_{1123}\right]\left[\mathrm{NH}_{2} \mathrm{C}_{3} \mathrm{SO}_{3}\right]\right)$ [39]. ${ }^{1} \mathrm{H}$ NMR $\left(400 \mathrm{MHz}, \mathrm{D}_{2} \mathrm{O}, \delta \mathrm{ppm}\right)$ 1.070-1.107 (t, 3H), 1.433-1.467 (t, 3H), 1.830-1.933 (m, 4H), 2.800-2.835 (t, 2H), 2.978-3.017 (t, 2H), $3.135(\mathrm{~s}, 6 \mathrm{H})$, 3.313-3.355 (t, 2H), 3.450-3.505 (q, 2H); ${ }^{13} \mathrm{C}$ NMR (100 MHz, $\left.\mathrm{D}_{2} \mathrm{O}, \delta \mathrm{ppm}\right): 7.678,10.171,15.712,27.536,39.783,49.102$, 49.978, 50.019, 50.060, 59.732, 65.039 .

Tetrabutylphosphonium imidazol ([P4444][Im]) [40]. ${ }^{1} \mathrm{H}$ NMR (400 MHz, $d_{6}$-DMSO, $\left.\delta \mathrm{ppm}\right): 0.902-0.937(\mathrm{t}, 12 \mathrm{H})$, 1.358-1.490 (m, 16H), 2.143-2.217 (m, 8H), $6.675(\mathrm{~s}, 2 \mathrm{H})$, $7.104(\mathrm{~s}, 1 \mathrm{H}) ;{ }^{13} \mathrm{C}$ NMR $\left(100 \mathrm{MHz}, d_{6}\right.$-DMSO, $\left.\delta \mathrm{ppm}\right): 141.52$ $124.38,23.91,23.75,23.17,23.15,18.05,17.58,13.73$.

1-Ethylpyridinium bis[(trifluoromethyl)sulfonyl]imide ([EPy][NTf 2$])$ [41]. ${ }^{1} \mathrm{H}$ NMR (400 MHz, $d_{6}$-DMSO, $\left.\delta \mathrm{ppm}\right)$ 1.549-1.585 (t, 3H), 4.625-4.680 (q, 2H), 8.112-8.147 (t, 2H), 8.553-8.592 (t, 1H), 9.076-9.090 (d, 2H); ${ }^{13} \mathrm{C}$ NMR $(100 \mathrm{MHz}$, $d_{6}$-DMSO, $\delta$ ppm): 16.024, 56.525, 114.729, 117.926, 121.124, $124.322,128.052,144.458,145.301$.

1-Methyl-1-Propylpiperidinium bis[(trifluoromethyl)sulfonyl] imide ([PP $\left.\left.{ }_{13}\right]\left[\mathrm{NTf}_{2}\right]\right)$ [41]. ${ }^{1} \mathrm{H}$ NMR (400 MHz, $d_{6}$-DMSO, $\delta$ ppm): 0.912-0.948 (t, 3H), 1.693-1.790 (m, 2H), $2.112(\mathrm{~s}, 4 \mathrm{H})$, 2.995 (s, 3H), 3.245-3.288 (m, 1H), 3.399-3.514 (m, 4H); ${ }^{13} \mathrm{C}$
NMR (100 MHz, $d_{6}$-DMSO, $\delta$ ppm): 10.250, 16.520, 21.041, 47.603, 63.529, 64.722, 114.756, 117.954, 121.151, 124.349 .

1-Ethyl-3-methylimidazolium hexafluorophosphate ([EM$\left.\operatorname{Im}]\left[\mathrm{PF}_{6}\right]\right)$ [43]. ${ }^{1} \mathrm{H} \quad \mathrm{NMR}\left(400 \mathrm{MHz}, d_{6}\right.$-DMSO, $\left.\delta \mathrm{ppm}\right):$ 1.395-1.430 (t, 3H), 3.838 (s, 3H), 4.154-4.206 (q, 2H), 7.639 (s, 1H), $7.721(\mathrm{~s}, 1 \mathrm{H}), 9.077(\mathrm{~s}, 1 \mathrm{H}) ;{ }^{13} \mathrm{C}$ NMR (100 MHz, d6DMSO, $\delta$ ppm): 15.023, 35.692, 44.229, 121.967, 123.580, 136.329

1-Butyl-3-methylimidazolium bis[(trifluoromethyl)sulfonyl] imide ([BMIm][NTf 2$]$ ) [44]. ${ }^{1} \mathrm{H}$ NMR (400 MHz, $d_{6}$-DMSO, $\delta$ ppm): 0.891-0.928 (t, 3H), 1.253-1.346 (m, 2H), 1.765-1.839 (m, 2H), 3.867 (s, 3H), 4.152-4.188 (t, 2H), $7.609(\mathrm{~s}, 1 \mathrm{H}), 7.672$ (s, 1H), $9.046(\mathrm{~s}, 1 \mathrm{H}) ;{ }^{13} \mathrm{C}$ NMR (100 MHz, $d_{6}$-DMSO, $\left.\delta \mathrm{ppm}\right)$ : 12.822, 18.759, 31.397, 35.573, 48.778, 114.842, 118.038, $121.234,122.211,123.547,124.430,136.536$.

1-Butyl-3-methylimidazolium chloride ([BMIm][Cl]) [45]. ${ }^{1} \mathrm{H}$ NMR (400 MHz, $d_{6}$-DMSO, $\delta \mathrm{ppm}$ ): 0.816-0.873 (t, $\left.3 \mathrm{H}\right)$, 1.191-1.203 (m, 2H), 1.728-1.763 (m, 2H), $3.898(\mathrm{~s}, 3 \mathrm{H})$, 4.214-4.244 (t, 2H), 7.492 (s, 1H), 8.037 (s, 1H), $9.817(\mathrm{~s}, 1 \mathrm{H})$; ${ }^{13} \mathrm{C}$ NMR (100 MHz, $d_{6}$-DMSO, $\delta$ ppm): 13.103, 18.606, 31.330, $35.585,48.218,122.203,123.411,136.726$.

1-(2-Hydroxyethyl)-3-methylimidazolium tetrafluoroborate ([HOEMIm][BF 4$])$ [42]. ${ }^{1} \mathrm{H}$ NMR $\left(400 \mathrm{MHz}, d_{6}\right.$-DMSO, $\left.\delta \mathrm{ppm}\right)$ : 3.729-3.753 (t, 2H), 3.849 (s, 3H), 4.186-4.211 (t, 2H), 5.049 (s, 1H), $7.564(\mathrm{~s}, 1 \mathrm{H}), 7.614(\mathrm{~s}, 1 \mathrm{H}), 8.894(\mathrm{~s}, 1 \mathrm{H}) ;{ }^{13} \mathrm{C}$ NMR $(100$ $\mathrm{MHz}, d_{6}$-DMSO, $\left.\delta \mathrm{ppm}\right):$ 35.821, 51.973, 59.662, 122.870, $123.556,136.989$.

1-(2-Hydroxyethyl)-3-methylimidazolium perfluorobutylsulfonate ([HOEMIm][NfO]) [42]. ${ }^{1} \mathrm{H}$ NMR (400 MHz, $d_{6}$-DMSO, $\delta \mathrm{ppm}): 3.736-3.772(\mathrm{t}, 2 \mathrm{H}), 3.872(\mathrm{~s}, 3 \mathrm{H}), 4.212-4.237(\mathrm{t}, 2 \mathrm{H})$, $5.077(\mathrm{~s}, 1 \mathrm{H}), 7.633(\mathrm{~s}, 1 \mathrm{H}), 7.676(\mathrm{~s}, 1 \mathrm{H}), 9.013(\mathrm{~s}, 1 \mathrm{H}) ;{ }^{13} \mathrm{C}$ NMR (100 MHz, $d_{6}$-DMSO, $\delta$ ppm): 35.737, 51.920, 59.628, 122.840, 123.511, 137.093; ${ }^{19} \mathrm{~F}$ NMR (376 MHz, $d_{6}$-DMSO, $\delta$ ppm): (-126.512)-(-126.378) (m, 2F), (-121.911)-(-121.836) $(\mathrm{m}, 2 \mathrm{~F}),(-115.263)-(-115.190)(\mathrm{t}, 2 \mathrm{~F}),(-81.689)-(-81.636)(\mathrm{t}$, $3 \mathrm{~F})$.

1-(2-Hydroxyethyl)-3-methylimidazolium hexafluorophosphate ([HOEMIm] [PF6]) [42]. ${ }^{1} \mathrm{H}$ NMR (400 MHz, $d_{6}$-DMSO, $\delta$ ppm): 3.733-3.759 (t, 2H), $3.855(\mathrm{~s}, 3 \mathrm{H}), 4.188-4.214(\mathrm{t}, 2 \mathrm{H})$, 5.123 (s, 1H), $7.573(\mathrm{~s}, 1 \mathrm{H}), 7.628(\mathrm{~s}, 1 \mathrm{H}), 8.973(\mathrm{~s}, 1 \mathrm{H}) ;{ }^{13} \mathrm{C}$ NMR (100 MHz, $d_{6}$-DMSO, $\delta$ ppm): 35.720, 51.882, 59.501, $122.782,123.422,136.949$.

1-(2-Hydroxyethyl)-3-methylimidazolium bis[(trifluoromethyl) sulfonyl]imide ([HOEMIm][NTf 2$])$ [42]. ${ }^{1} \mathrm{H}$ NMR (400 MHz, $d_{6}$-DMSO, $\delta$ ppm): 3.725-3.750 (t, 2H), $3.858(\mathrm{~s}, 3 \mathrm{H})$, 4.191-4.216 (t, 2H), $5.136(\mathrm{~s}, 1 \mathrm{H}), 7.604(\mathrm{~s}, 1 \mathrm{H}), 7.652(\mathrm{~s}, 1 \mathrm{H})$, $9.032(\mathrm{~s}, 1 \mathrm{H}) ;{ }^{13} \mathrm{C}$ NMR $\left(100 \mathrm{MHz}, d_{6}\right.$-DMSO, $\left.\delta \mathrm{ppm}\right): 35.740$, 51.889, 59.512, 114.947, 118.145, 121.342, 122.809, 123.436, $124.540,137.031$.

\subsection{Reaction procedure for the carbonylation of glycerol}

The carbonylation of glycerol with urea was conducted in a $50 \mathrm{~mL}$ round bottom flask (Scheme 1) equipped with a magnetic stirrer and condenser. In a typical reaction, glycerol (50 mmol) and urea $(75 \mathrm{mmol})$ were added into the round bottom flask and treated at $150{ }^{\circ} \mathrm{C}$ under reduced pressure for $4 \mathrm{~h}$. The 


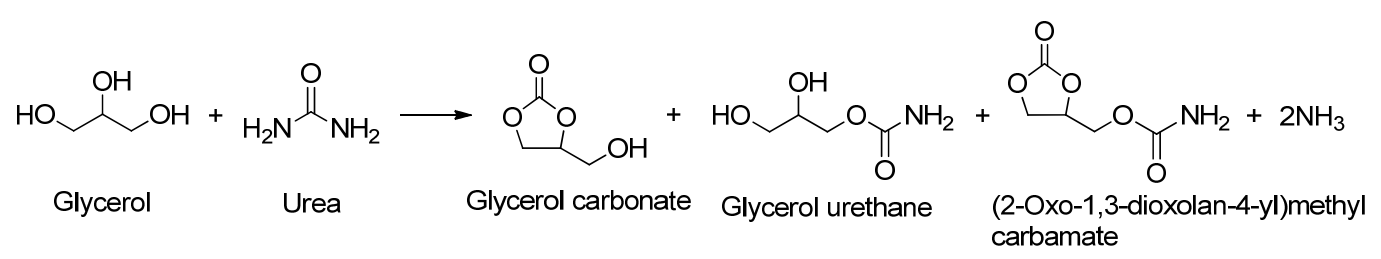

Scheme 1. Synthesis of glycerol carbonate by the carbonylation of glycerol.

desired amount of catalyst ( $3 \mathrm{mmol}$ unless otherwise specified) was then added and the resulting mixture was heated to the desired temperature in an oil bath. The reactions were run under $\mathrm{N}_{2}$ flow in order to remove the $\mathrm{NH}_{3}$ byproduct. The reaction progress was followed by ${ }^{1} \mathrm{H}$ NMR spectroscopy. The conversion, selectivity and yield were calculated by ${ }^{1} \mathrm{H}$ NMR spectroscopy based on the glycerol.

\section{Results and discussion}

\subsection{Carbonylation of glycerol at different temperatures}

We describe here the carbonylation reactions of glycerol with urea by the ionic liquid catalysts described above. Since the utilization of an IL as catalyst for this reaction has not been studied, our first investigation focused on the model reaction of glycerol and urea to form glycerol carbonate with the IL [HOEMIm] [PF6]. The effect of temperature on the reaction was first investigated. The reaction profiles over [HOEMIm] $\left[\mathrm{PF}_{6}\right]$ with temperature are depicted in Fig. 2. As the reaction temperature was increased from 100 to $170{ }^{\circ} \mathrm{C}$, a remarkable increase in glycerol conversion and yield of desired glycerol carbonate was observed when the temperature was lower than $150{ }^{\circ} \mathrm{C}$. However, both the conversion and yield of glycerol carbonate rapidly decreased on further increasing the temperature, which can be attributed to the decomposition of urea at this temperature [46]. The selectivity of glycerol carbonate varied with temperature. The highest selectivity of $66 \%$ was attained at $140{ }^{\circ} \mathrm{C}$, which was probably because the intermediate giving the desired product was formed at temperatures lower than

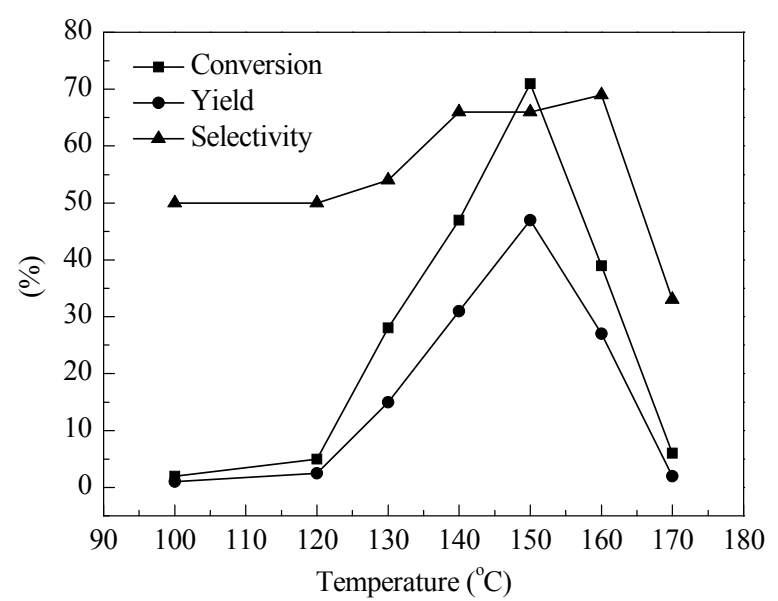

Fig. 2. Effect of reaction temperature on the carbonylation of glycerol catalyzed by [HOEMIm] $\left[\mathrm{PF}_{6}\right]$. Reaction conditions: glycerol $50 \mathrm{mmol}$, urea $75 \mathrm{mmol}$, IL $3 \mathrm{mmol}, 4 \mathrm{~h}$.
$140{ }^{\circ} \mathrm{C}$ and was consumed when the temperature was higher [12]. Based on this result, the optimal reaction temperature was controlled at $150^{\circ} \mathrm{C}$ for further investigation.

\subsection{Carbonylation of glycerol dependence on reaction time}

The influence of reaction time on the synthesis of glycerol carbonate was also investigated. The results are shown in Fig. 3. The conversion of glycerol increased from $9 \%$ to $74 \%$ with reaction time from 1 to $6 \mathrm{~h}$, during which a turning point at $4 \mathrm{~h}$ was observed, after which the conversion of glycerol only slightly increased. However, the selectivity and yield of glycerol carbonate slightly decreased with time, possibly due to the further reaction of glycerol carbonate with urea to form (2-oxo1,3-dioxolan-4-yl)methyl carbamate [10]. For this reason, the reaction time was fixed at $4 \mathrm{~h}$ for the remaining runs.

\subsection{Influence of the molar ratio of glycerol/urea}

The molar ratio of the substrates is an important factor for chemical reactions. The effect of molar ratio of glycerol to urea on the conversion, selectivity and yield of the glycerol carbonylation was investigated. The molar ratio of glycerol to urea was varied from 1:0.5 to 1:2.5. The result is shown in Fig. 4. The conversion of glycerol increased from $34 \%$ to $78 \%$ with increasing the molar ratio of glycerol to urea from 1:0.5 to 1:2.5. However, the selectivity of glycerol carbonate decreased from $94 \%$ to $32 \%$. As a result, the yield of glycerol carbonate increased initially from $33 \%$ to a maximum value of $47 \%$ when the molar ratio was 1:1.5. After that, the yield decreased gradu-

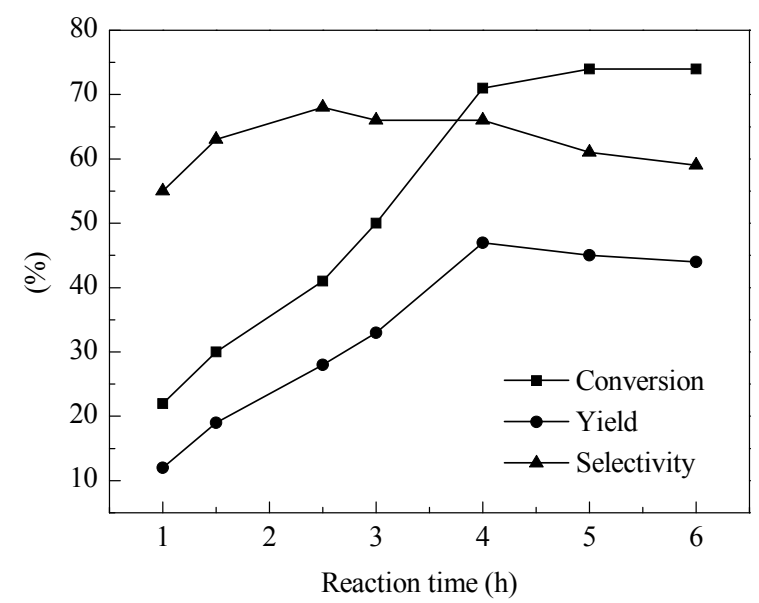

Fig. 3. Effect of reaction time on the carbonylation of glycerol catalyzed by $[\mathrm{HOEMIm}]\left[\mathrm{PF}_{6}\right]$. Reaction conditions: glycerol $50 \mathrm{mmol}$, urea $75 \mathrm{mmol}$, IL $3 \mathrm{mmol}, 150^{\circ} \mathrm{C}$. 


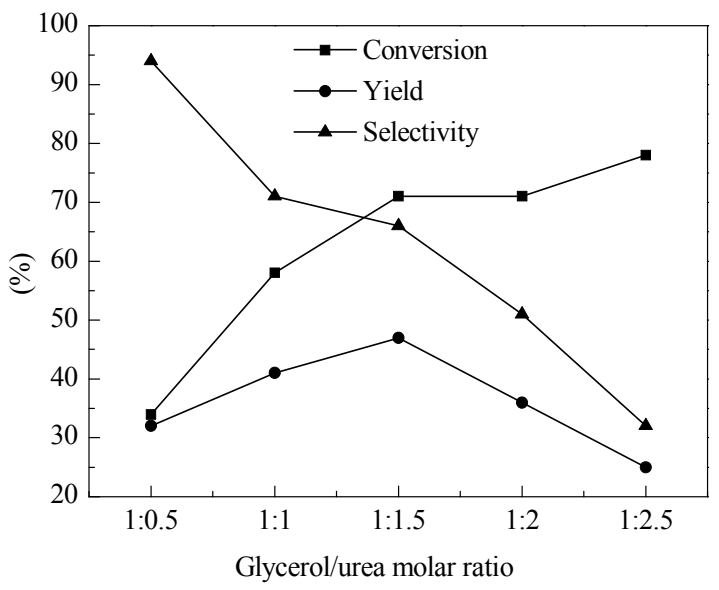

Fig. 4. Effect of molar ratio of the reagents on the carbonylation of glycerol catalyzed by [HOEMIm] $\left[\mathrm{PF}_{6}\right]$. Reaction conditions: glycerol 50 mmol, catalyst $3 \mathrm{mmol}, 4 \mathrm{~h}, 150^{\circ} \mathrm{C}$.

ally. Therefore, the molar ratio was fixed at 1:1.5 for further experiments.

\subsection{Determination of the optimal quantity of IL required as catalyst}

The effect of catalyst amount on the carbonylation of glycerol was investigated. The reaction condition was $150{ }^{\circ} \mathrm{C}, 4 \mathrm{~h}$ reaction time with nitrogen flow (Fig. 5). The conversion, selectivity and yield increased gradually with the loaded amount of catalyst [HOEMIm] $\left[\mathrm{PF}_{6}\right]$ and reached their optimal values when the amount of catalyst was $6 \mathrm{~mol} \%$, when the conversion was $71 \%$ and the selectivity was $66 \%$, thus giving a best yield of $47 \%$. On further increasing the amount of [HOEMIm] [PF6], both conversion and selectivity decreased, with a concomitantly decreased yield. For this reason, 6 mol\% catalyst was used throughout this work.

\subsection{Comparison of catalytic activity with different ILs}

In addition, we used the various ILs to catalyze the carbonylation of glycerol with urea. The catalytic activity of the

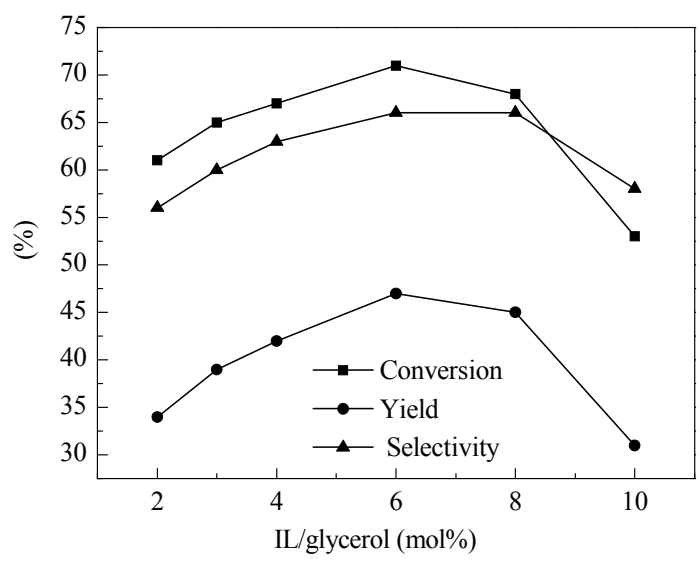

Fig. 5. Effect of IL amount on the carbonylation of glycerol catalyzed by [HOEMIm] [PF 6 . Reaction conditions: glycerol $50 \mathrm{mmol}$, urea $75 \mathrm{mmol}$, $150^{\circ} \mathrm{C}, 4 \mathrm{~h}$.
Table 1

Catalytic activity of the ionic liquids in the reaction of glycerol with urea.

\begin{tabular}{|c|c|c|c|}
\hline Entry & IL & Glycerol conversion (\%) & GC yield (\%) \\
\hline 1 & Blank $^{[13]}$ & 59 & 21 \\
\hline 2 & {$\left[\mathrm{~N}_{1123}\right]\left[\mathrm{NH}_{2} \mathrm{C}_{3} \mathrm{SO}_{3}\right]$} & 53 & 35 \\
\hline 3 & [BMIm][ALa] & 56 & 36 \\
\hline 4 & {$\left[\mathrm{P}_{4444}\right][\mathrm{Im}]$} & 52 & 31 \\
\hline 5 & {$[\mathrm{TEBSA}]\left[\mathrm{HSO}_{4}\right]$} & 44 & 33 \\
\hline 6 & {$\left[\mathrm{MImC}_{4} \mathrm{SO}_{3} \mathrm{H}\right]\left[\mathrm{NTf}_{2}\right]$} & 44 & 27 \\
\hline 7 & [TMBSA][NTf 2$]$ & 51 & 27 \\
\hline 8 & {$\left[\mathrm{PP}_{13}\right]\left[\mathrm{NTf}_{2}\right]$} & 76 & 40 \\
\hline 9 & [EPy] $\left[\mathrm{NTf}_{2}\right]$ & 70 & 40 \\
\hline 10 & {$[\mathrm{BMIm}]\left[\mathrm{NTf}_{2}\right]$} & 70 & 42 \\
\hline 11 & {$[\mathrm{EMIm}]\left[\mathrm{PF}_{6}\right]$} & 62 & 47 \\
\hline 12 & [HOEMIm][NTf 2$]$ & 64 & 52 \\
\hline 13 & [HOEMIm][PF 6$]$ & 71 & 47 \\
\hline 14 & [HOEMIm][NfO] & 65 & 38 \\
\hline 15 & {$[\mathrm{HOEMIm}]\left[\mathrm{BF}_{4}\right]$} & 54 & 39 \\
\hline 16 & [BMIm][Cl] & 58 & 25 \\
\hline
\end{tabular}

different ILs is summarized in Table 1. The nature of the ILs showed a significant effect on the catalytic performance. In the absence of a catalyst, the conversion of glycerol was $59 \%$ and the yield of glycerol carbonate was only $21 \%$ (entry 1). For basic $\left[\mathrm{N}_{1123}\right]\left[\mathrm{NH}_{2} \mathrm{C}_{3} \mathrm{SO}_{3}\right]$, [BMIm] [ALa], and [ $\left.\mathrm{P}_{4444}\right][\mathrm{Im}]$ (entries $2-4$ ), the conversions were $53 \%, 56 \%$, and $52 \%$, and the yields of glycerol carbonate were $35 \%, 36 \%$, and $31 \%$, respectively. It can be concluded that the basic ILs did not improve the reaction. For the acidic [TEBSA][HSO $\left.{ }_{4}\right],\left[\mathrm{MImC}_{4} \mathrm{SO}_{3} \mathrm{H}\right]\left[\mathrm{NTf}_{2}\right]$, and [TMBSA] [NTf 2 ] ILs (entries 5-7), the conversions of glycerol were $44 \%, 44 \%$, and $51 \%$, respectively, which were slightly lower than that of the blank experiment. This suggested that acidic ILs did not favor the glycerol conversion. The yields were $33 \%, 27 \%$, and $27 \%$, respectively, which were also lower than the blank system. From these results, we can see that both acidic ILs and basic ILs were not good catalysts for the carbonylation of glycerol with urea. Previous reports have suggested that the excellent performance of the catalyst can be attributed to the existence of a good balance of acid-base properties, and strong Lewis acid or basic sites promoted the formation of byproducts $[10,11]$.

In contrast, as compared to acidic and basic ILs, most neutral ILs exhibited good catalytic performance. For instance, the use of $\left[\mathrm{PP}_{13}\right]\left[\mathrm{NTf}_{2}\right]$ as catalyst gave the highest conversion of $76 \%$ (entry 8). Even the lowest conversion of $54 \%$ found in the [HOEMIm] $\left[\mathrm{BF}_{4}\right]$ system was close to the blank reaction. The other seven ILs gave conversions ranging from 58\% to $71 \%$, close to or higher than that of the blank system. A high yield was obtained for all these ILs expect [BMIm][Cl]. For example, [HOEMIm][NTf 2 (entry 12) gave the highest yield of $52 \%$ and entries 8-11 and 13-15 gave yields close to or a bit higher than $40 \%$, which were almost twice that of the blank experiment. The good catalytic performance of the neutral ILs may be attributed to their special structure and properties. It has been reported that a cooperative effect between weak Lewis acid sites and Lewis basic sites is responsible for good catalytic performance where the weak Lewis acid sites activate the car- 
bonyl group of urea and the Lewis basic sites activate glycerol [10]. In our currently investigated system, the ILs consist of a positively charged cation, like 1-alkyl-3-methylimidazolium, tetrabutylphosphonium, and 1-ethylpyridinium, and a negatively charged anion, including bis[(trifluoromethyl)sulfonyl] imide ( $\left.\mathrm{NTf}_{2}\right)$, hexafluorophosphate $\left(\mathrm{PF}_{6}\right)$, and tetrafluoroborate $\left(\mathrm{BF}_{4}\right)$. The positively charged cation attracts the electronegative oxygen of the carbonyl group of urea and the electrostatic attraction between the cation of the IL and the carbonyl group activates urea, that is, the cation of the ILs plays a similar role to that of the Lewis acid of the previously reported metal catalysts. This is an important feature of the catalyst for achieving high yields of the cyclic carbonate [47]. The basicity of ILs has been intensively studied by the Welton's group [48]. We consider that the negatively charged anion of the ILs attracts the proton of glycerol, and moreover, the $\mathrm{F}$ atoms of $\mathrm{BF}_{4}$ or $\mathrm{PF}_{6}$ and $\mathrm{O}$ atoms of sulfonyl of $\mathrm{NTf}_{2}$ can form hydrogen bonds with the hydroxyl group of glycerol. All these interactions activate glycerol, which is also responsible for the high catalytic activity of these ILs [10].

It is known that the properties of an IL depend on both its cation and anion and are tunable by the combination of different cations and anions. Therefore, their catalytic performance is dependent on the counter ions of the ILs. In this section, the effect of the counter ion of the ILs was further investigated. As shown in Table 1, entries 6-10 and 12 have the same anion of [NTf 2 , and the acidic $\left[\mathrm{MImC}_{4} \mathrm{SO}_{3} \mathrm{H}\right]\left[\mathrm{NTf}_{2}\right]$ (entry 6) and [TMBSA][NTf 2 ] (entry 7) gave conversions of $44 \%$ and $51 \%$, and a same yield of $27 \%$, respectively. For the neutral [PP13][NTf 2$]$ (entry 8), [EPy][NTf 2$]$ (entry 9), [BMIm][NTf 2$]$ (entry 10), and [HOEMIm] [NTf 2 ] (entry 12), both conversion and yield were higher than those observed with the acidic IL systems. Although the latter four ILs have different cations, the cation had no obvious effect on the catalytic activity. The rea-

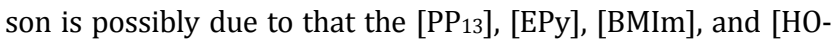
EMIm] cations of the ILs were all quaternary ammonium salts that have similar properties. Moreover, we can see that [EM$\mathrm{Im}]\left[\mathrm{PF}_{6}\right]$ (entry 11) and [HOEMIm] $\left[\mathrm{PF}_{6}\right]$ (entry 13) have also the same anion, and the former gave a conversion of $62 \%$ and a yield of $47 \%$, and the latter gave a conversion of $71 \%$ and a yield of $47 \%$. Again, no obvious difference in catalytic performance was observed for these two ILs. We can also attribute this to the similar structure and properties of [EMIm] and [HOEMIm] of the ILs, which therefore confirms our assumption.

The organo-catalytic potential was highlighted as "dual activation through a cooperative effect of charge-charge interaction and hydrogen bond formation involving the cation and anion of the imidazolium-based ILs" by Chakraborti and co-workers [49-51] through the identification of the respective supramolecular assemblies. For example, in the Aza-Michael reaction of 1,3-diphenyl-2-propenone with aniline, the IL 1butyl-3-methylimidazolium methylsulfate ([BMIM][MeSO 4$]$ ) was found to be the most effective and afforded the desired Adz-Michael adduct in high yield [49]. The supramolecular assemblies of reactants formed by a relay of cooperative hydrogen bonds (formed by the C-2 hydrogen of 1-butyl-3-me- thylimidazolium cation and the carbonyl oxygen of 1,3-diphenyl-2-propenone; hydrogen of aniline and oxygen of methylsulfate anion) and charge-charge interaction (positively charged 1-butyl-3-methylimidazolium and negatively charged methylsulfate) promoted the Aza-Michael reaction. However, in

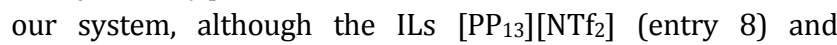
[EPy][NTf 2 (entry 9) do not possess a C-2 hydrogen, they exhibited almost same catalytic performance as [bmim] [NTf 2 , which has a C-2 hydrogen (entry 10). These results revealed that there was no so-called "dual activation" in the currently investigated reaction.

In addition, we also investigated the effect of the anion of the ILs on the reaction by keeping the cation the same (entries 12-15 that use [HOEMIm] as cation). The anions we chose were $\left[\mathrm{NTf}_{2}\right],\left[\mathrm{PF}_{6}\right],[\mathrm{NfO}]$, and $\left[\mathrm{BF}_{4}\right]$. The conversions of these catalytic systems were $64 \%, 71 \%, 65 \%$, and $54 \%$ and the yields were $52 \%, 47 \%$, 38\%, and 39\%, respectively. These differences in both conversion and yield were also not obvious, so we cannot extract any regularity between the anions of the ILs and their catalytic performance. The hydrogen bond basicity $(\beta)$ of

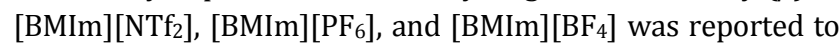
be $0.42,0.44$, and 0.55 , respectively [52]. Since these three ILs have the same cation, it can be suggested that [HOEMIm] [NTf 2 , [HOEMIm] $\left[\mathrm{PF}_{6}\right]$, and $[\mathrm{HOEMIm}]\left[\mathrm{BF}_{4}\right]$ should have a similar hydrogen bond basicity. This may be the reason why the above three ILs exhibited similar catalytic performance. Although we did not find the hydrogen bond basicity for either [HOEMIm][NfO] or [BMIm][NfO], the IL 1-butyl-3-methylimidazolium trifluomethanesulfonate ([BMIm] $\left.\left[\mathrm{CF}_{3} \mathrm{SO}_{3}\right]\right)$ was reported to have a hydrogen bond basicity of 0.57 (i.e. $\beta=0.57$ ) [52], a value close to the 0.55 of $[\mathrm{BMIm}]\left[\mathrm{BF}_{4}\right]$. We need to notice that [BMIm][NfO] and $[\mathrm{BMIm}]\left[\mathrm{CF}_{3} \mathrm{SO}_{3}\right]$ have a similar anionic structure, from which we can speculate that [BMIm][NfO] should have a similar $\beta$ value to $[\mathrm{BMIm}]\left[\mathrm{CF}_{3} \mathrm{SO}_{3}\right]$ and thus $[\mathrm{BMIm}]\left[\mathrm{BF}_{4}\right]$. In other words, the hydrogen bond basicity of [HOEMIm][NfO] should be close to those of [BMIm][NTf 2 , $[\mathrm{BMIm}]\left[\mathrm{PF}_{6}\right]$, and $[\mathrm{BMIm}]\left[\mathrm{BF}_{4}\right]$. This result further supported our conclusion. Although [BMIm] [Cl] is also a neutral IL, it gave a relatively low conversion and yield. The reason is not yet clear, but the hydrogen bond basicity of the IL is 0.95 , which is much higher than that of the other ILs (in general, the ILs have a $\beta$ value ranging from 0.4 to 0.8 ). This may be detrimental to the good balance of the acid-basic properties of the ILs that gave the ILs the optimal catalytic performance.

\subsection{Recyclability of the ionic liquids}

A series of recycle experiments were carried out to investigate the stability of the IL catalyst. In our experiments, some reaction systems were found to form two phases with the ILs at the bottom of the flask, as detected by NMR spectroscopy. This indicated that the ILs were immiscible with the reaction mixture when the reaction was completed. This is of importance for the homogeneous catalysis as this means that the catalysts can be recovered easily by simple decantation. Therefore, we chose $[\mathrm{BMIm}]\left[\mathrm{NTf}_{2}\right]$ to investigate the recyclability of the catalyst in this reaction. [BMIm][NTf 2 ] was not soluble in the reac- 


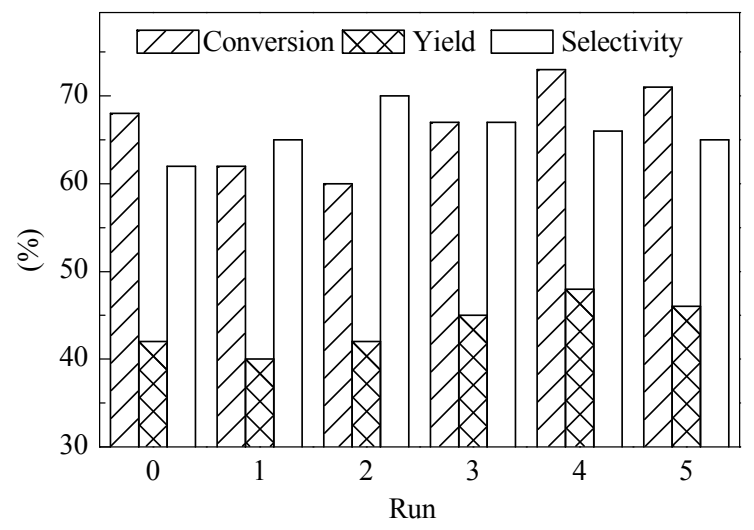

Fig. 6. Recycling of $[\mathrm{BMIm}]\left[\mathrm{NTf}_{2}\right]$. Reaction conditions: glycerol 50 mmol, urea $75 \mathrm{mmol}$, IL $3 \mathrm{mmol}, 150^{\circ} \mathrm{C}, 4 \mathrm{~h}$.

tion mixture at the end of the reaction when the mixture was cooled down to room temperature. In order to reduce the loss of the IL, $5 \mathrm{~mL}$ water was added to the mixture and the mixture was stirred at room temperature for $30 \mathrm{~min}$. The [BMIm] [NTf 2 ] phase was at the bottom of the flask and was recovered by decantation of the liquid. The recovered IL was dried under vacuum to remove water and then reused for the next cycle. The same procedure was repeated 5 times. The catalytic results are shown in Fig. 6. It can be seen that there was no obvious change in the conversion of glycerol and selectivity of glycerol carbonate, suggesting that [BMIm] $\left.\mathrm{NTf}_{2}\right]$ as the catalyst for the carbonylation of glycerol with urea was stable enough to be recycled at least 5 times. A similar result was also obtained for [BMIm] $\left[\mathrm{NTf}_{2}\right],\left[\mathrm{PP}_{13}\right]\left[\mathrm{NTf}_{2}\right]$, and $[\mathrm{EMIm}]\left[\mathrm{PF}_{6}\right]$.

\section{Conclusions}

The carbonylation of glycerol with urea was carried with ionic liquids (ILs) as catalyst. The optimal reaction conditions were explored. Acidic and basic ILs were not good catalysts for this reaction. However, neutral ILs exhibited high catalytic activity. This was attributed to the good balance of the acid-base properties of the neutral ILs. The positively charged cations attract the electronegative oxygen of the carbonyl group of urea, thus activating urea. The cation of the ILs was considered to play a similar role to that of the Lewis acid of metal catalysts. The negatively charged anions of the ILs attract the proton of glycerol, and the fluorine atoms of $\mathrm{BF}_{4}$ or $\mathrm{PF}_{6}$ and oxygen atoms of sulfonyl of $\mathrm{NTf}_{2}$ can form hydrogen bonds with the hydroxyl group of glycerol. These interactions activate glycerol, which was responsible for the high catalytic activity of the ILs. The effect of both cation and anion on the reaction was further investigated. It appeared that the catalytic performance of the ILs was related to their hydrogen bond basicity, which follows the mechanism of metal catalysts where the existence of a good balance of acid-basic properties of the catalyst was proposed. The ILs can be recovered and reused at least five times without loss of activity.

\section{References}

[1] Ma F R, Hanna M A. Bioresour Technol, 1999, 70: 1

[2] Behr A, Eilting J, Irawadi K, Leschinski J, Lindner F. Green Chem, 2008, 10: 13

[3] Zhou C H, Beltramini J N, Fan Y X, Lu G Q. Chem Soc Rev, 2008, 37: 527

[4] Sonnati M O, Amigoni S, de Givenchy E P T, Darmanin T, Choulet O, Guittard F. Green Chem, 2013, 15: 283

[5] Hu J L, Li J J, Gu Y L, Guan Z H, Mo W L, Ni Y M, Li T, Li G X. Appl Catal A, 2010, 386: 188

[6] Lim Y N, Lee C, Jang H Y. Eur J Org Chem, 2014: 1823

[7] Strain F. US Patent 2446 145. 1948

[8] Patel Y, George J, Pillai S M, Munshi P. Green Chem, 2009, 11: 1056

[9] Kim S C, Kim Y H, Lee H, Yoon D Y, Song B K. J Mol Catal B, 2007, 49: 75

[10] Climent M J, Corma A, Frutos P D, Iborra S, Noy M, Velty A, Concepción P. J Catal, 2010, 269: 140

[11] Wang L G, Ma Y B, Wang Y, Liu S M, Deng Y Q. Catal Commun, 2011, 12: 1458

[12] Turney T W, Patti A, Gates W, Shaheen U, Kulasegaram S. Green Chem, 2013, 15: 1925

[13] Rahim M H A, He Q, Lopez-Sanchez J A, Hammond C, Dimitratos N, Sankar M, Carley A F, Kiely C J, Knight D W, Hutchings G J. Catal Sci Technol, 2012, 2: 1914

\section{Graphical Abstract}

Chin. J. Catal., 2015, 36: 336-343 doi: 10.1016/S1872-2067(14)60257-6

Ionic liquids as eco-friendly catalysts for converting glycerol and urea into high value-added glycerol carbonate

Juanjuan Chen, Chang Wang, Bin Dong, Wenguang Leng, Jun Huang*, Rile Ge, Yanan Gao*

Nanjing Tech University;

Dalian Institute of Chemical Physics, Chinese Academy of Sciences

High value-added glycerol carbonate was obtained from glycerol and urea by using ionic liquids (ILs) as eco-friendly catalysts. Neutral ILs showed higher catalytic activity than acidic and basic ones and the balanced acid-base properties of the neutral catalysts are responsible for their catalytic performance. The ILs can be recovered and reused for more than five successive reactions without loss of activity.

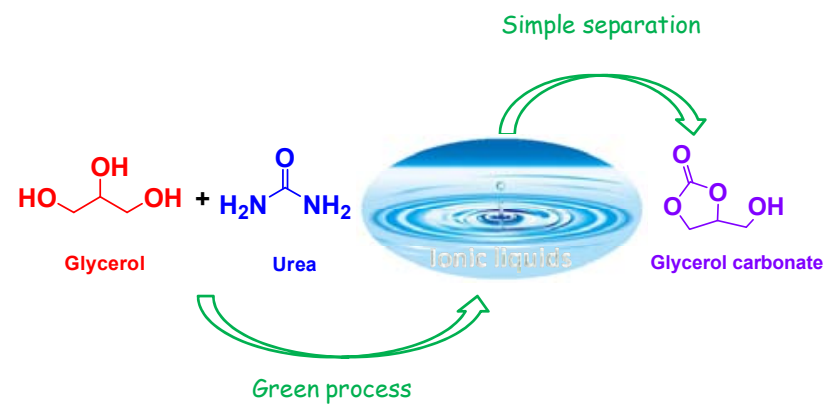


[14] Jagadeeswaraiah K, Kumar C R, Prasad P S S, Loridant S, Lingaiah N. Appl Catal A, 2014, 469: 165

[15] Fujita S I, Yamanishi Y, Arai M. J Catal, 2013, 297: 137

[16] Sandesh S, Shanbhag G V, Halgeri A B. RSC Adv, 2014, 4: 974

[17] Claude S, Mouloungui Z, Yoo J W, Gaset A. US Patent 6025504. 2000

[18] Lee M S, Baek J H. US Patent 2013026 771 5A1. 2013

[19] Buzzeo M C, Evans R G, Compton R G. ChemPhysChem, 2004, 5: 1106

[20] Macfarlane D R, Forsyth M, Howlett P C, Pringle J M, Sun J, Annat G, Neil W, Izgorodina E I. Acc Chem Res, 2007, 40: 1165

[21] Liu H T, Liu Y, Li J H. Phys Chem Chem Phys, 2010, 12: 1685

[22] Mulik A, Chandam D, Patil P, Patil D, Jagdale S, Deshmukh M. J Mol Liq, 2013, 179: 104

[23] Welton T. Chem Rev, 1999, 99: 2071

[24] Cole A C, Jensen J L, Ntai I, Tran K L T, Weaver K J, Forbes D C, Davis J H. J Am Chem Soc, 2002, 124: 5962

[25] Forbes D C, Weaver K J. J Mol Catal A, 2004, 214: 129

[26] Gu Y L, Shi F, Deng Y Q. Catal Commun, 2003, 4: 597

[27] Nockemann P, Thijs B, Parac-Vogt T N, Van Hecke K, Van Meervelt L, Tinant B, Hartenbach I, Schleid T, Ngan V T, Nguyen M T, Binnemans K. Inorg Chem, 2008, 47: 9987

[28] Bates E D, Mayton R D, Ntai I, Davis J H. J Am Chem Soc, 2002, 124: 926

[29] Sarkar A, Roy S R, Parikh N, Chakraborti A K. J Org Chem, 2011, 76: 7132

[30] Sarkar A, Roy S R, Chakraborti A K. Chem Commun, 2011, 47: 4538

[31] Park D W, Mun N Y, Kim K H, Kim I, Park S W. Catal Today, 2006, 115: 130

[32] Tharun J, Kathalikkattil A C, Roshan R, Kang D H, Woo H C, Park D W. Catal Commun, 2014, 54: 31

[33] Ju H Y, Manju M D, Kim K H, Park S W, Park D W. J Ind Eng Chem, 2008, 14: 157
[34] Kim D W, Roshan R, Tharun J, Cherian A, Park D W. Korean J Chem Eng, 2013, 30: 1973

[35] Kim M I, Choi S J, Kim D W, Park D W. J Ind Eng Chem, 2014, 20: 3102

[36] Kim D W, Kim C W, Koh J C, Park D W. J Ind Eng Chem, 2010, 16: 474

[37] Saravanamurugan S, Riisager A. Catal Today, 2013, 200: 94

[38] Fukumoto K, Yoshizawa M, Ohno H. J Am Chem Soc, 2005, 127: 2398

[39] Wang C, Liu X M, Yang M, Ma H Y, Yan P F, Slattery J M, Gao Y A. RSC Adv, 2013, 3: 8796

[40] Wang C, Liu J, Leng W G, Gao Y A. Int J Mol Sci, 2014, 15: 1284

[41] Singh A, Kumar A. J Org Chem, 2012, 77: 8775

[42] Zhang S G, Qi X J, Ma X Y, Lu L J, Deng Y Q. J Phys Chem B, 2010, 114: 3912

[43] Matsumoto K, Hagiwara R, Yoshida R, Ito Y, Mazej Z, Benkič P, Žemva B, Tamada O, Yoshino H, Matsubara S. Dalton Trans, 2004: 144

[44] Srour H, Rouault H, Santini C C, Chauvin Y. Green Chem, 2013, 15: 1341

[45] Cull S G, Holbrey J D, Vargas-Mora V, Seddon K R, Lye G J. Biotechnol Bioeng, 2000, 69: 227

[46] Schaber P M, Colson J, Higgins S, Thielen D, Anspach B, Brauer J. Thermochim Acta, 2004, 424: 131

[47] Li Q B, Zhang W Y, Zhao N, Wei W, Sun Y H. Catal Today, 2006, 115: 111

[48] Cláudio A F M, Swift L, Hallett J P, Welton T, Coutinho J A P, Freire M G. Phys Chem Chem Phys, 2014, 16: 6593

[49] Roy S R, Chakraborti A K. Org Lett, 2010, 12: 3866

[50] Chakraborti A K, Roy S R. J Am Chem Soc, 2009, 131: 6902

[51] Chakraborti A K, Roy S R, Kumar D, Chopra P. Green Chem, 2008, 10: 1111

[52] Lungwitz R, Strehmel V, Spange S. New J Chem, 2010, 34: 1135

\title{
离子液体催化甘油和尿素合成甘油碳酸酯
}

\author{
陈娟娟 ${ }^{\mathrm{a}}$, 王 畅 ${ }^{\mathrm{b}}$, 董 涁 ${ }^{\mathrm{b}}$, 冷文光 ${ }^{\mathrm{b}}$, 黄 军 ${ }^{\mathrm{a},{ }^{*}}$, 格日乐 ${ }^{\mathrm{b}}$, 高艳安, ${ }^{\mathrm{b}, \#}$ \\ a南京工业大学化学化工学院, 江苏南京210009 \\ ${ }^{b}$ 中国科学院大连化学物理研究所, 辽宁大连 116023
}

摘要: 将一系列酸性、碱性和中性的功能化离子液体用于催化甘油和尿素合成甘油碳酸酯. 结果表明, 中性离子液体表现出更高 的催化活性. 离子液体阳离子和阴离子的协同效应促进了反应的进行, 离子液体阳离子的正电性活化尿素, 阴离子的负电性活化 甘油, 并且催化剂酸碱位点的平衡对催化反应过程也有一定的影响. 此外, 离子液体可以实现回收利用至少五次, 且催化活性基本 不变. 采用功能化离子液体替代传统金属催化剂, 减少了不可再生资源的利用, 且所用原料为廉价易得的生物基原料,过程中也不 使用有机溶剂,环境友好.

关键词: 甘油碳酸酯; 甘油; 尿素; 离子液体

收稿日期: 2014-10-16. 接受日期: 2014-11-19. 出版日期: 2015-03-20.

*通讯联系人. 电话: (025)83172276; 电子信箱: junhuang@njtech.edu.cn

\#通讯联系人. 电话/传真: (0411)84379992; 电子信箱: ygao@dicp.ac.cn

基金来源：国家自然科学基金(21273235, 21303076); 中国科学院“百人计划”.

本文的英文电子版由Elsevier出版社在ScienceDirect上出版(http://www.sciencedirect.com/science/journal/18722067). 